\title{
Cnidoscolus (Euphorbiaceae) escaped in Malesia?
}

\author{
P.C. van Welzen ${ }^{1,2}$, F.J. Fernández-Casas ${ }^{3}$
}

\section{Key words}

Cnidoscolus

Euphorbiaceae

introduced species

Jatropha

Malesia

revision

\begin{abstract}
The genus Cnidoscolus, a species rich genus in the Americas, has been introduced in the Philippines. A cultivar of Cnidoscolus aconitifolius is used as vegetable and has been collected from gardens in Manila and Pasay City and two times near Cebu City. It cannot be excluded that it has escaped cultivation there, but the species does not appear to be invasive.
\end{abstract}

Published on 21 April 2017

\section{INTRODUCTION}

Cnidoscolus Pohl is a genus new to Malesia. It is used in the Philippines as vegetable, but was found outside cultivation near Cebu City. Therefore, a short introduction to this vegetable and a description of the cultivar is presented comparable to the treatment of Ricinus communis L. (Van Welzen 1998). A generic description can be found in Radcliffe-Smith (2001). Pohl (1827) established the genus Cnidoscolus by separating it from Jatropha L. Cnidoscolus species (67 in Govaerts et al. 2000 , but many newly described since) generally have many stinging bristle hairs, often called urticating hairs (e.g., RadcliffeSmith 2001: 273). They lack the attractive red to purple petals of Jatropha, though the petaloid sepals are often white and showy. Subsequent authors, most importantly Müller Argoviensis $(1865,1866)$ and $\operatorname{Pax}(1890,1910)$ treated Cnidoscolus as a section (Müller Argoviensis 1866) or subgenus (Pax 1890) of Jatropha. Starting with Grisebach (1864) Cnidoscolus was reinstated as genus, which was also followed by Pax \& Hoffmann (1931).

In morphology-based classifications Cnidoscolus is placed in subfamily Crotonoideae Pax tribe Manihoteae (Müll.Arg.) Pax (Webster 1994, 2014, Radcliffe-Smith 2001). The molecular phylogeny of Wurdack et al. (2005), based on $r b c L$ and $t r n L-F$, confirms the morphological classification, and it shows Cnidoscolus to be part of the clade 'articulated crotonoids', which also contains Manihot Mill., but which is surprisingly separate from their clade C1, which comprises Jatropha. Their sister clades C1 and C2 are in turn sister to the 'articulated crotonoids' (Wurdack et al. 2005: f. 4), thus Jatropha is not closely related to Cnidoscolus. The most recent and still used infrageneric classification is by McVaugh (1944).

A cultivar of one species, C. aconitifolius (Mill.) I.M.Johnst., was introduced in the Philippines, and at least four specimens are known: two specimens were collected from cultivated plants (PNH (Manuel) 18631, Steiner 1085), in 1954 and 1956, respec-

\footnotetext{
${ }^{1}$ Naturalis Biodiversity Center, research group Biodiversity Discovery, P.O. Box 9517, 2300 RA Leiden, The Netherlands;

corresponding author e-mail: peter.vanwelzen@naturalis.nl.

2 Institute of Biology Leiden, Leiden University, P.O. Box 9505, 2300 RA Leiden, The Netherlands.

${ }^{3}$ Campanario, Badajoz; formerly: Real Jardín Botánico, CSIC, Plaza de Murillo 2, E-28014 Madrid, Spain; e-mail: fjfcasas@yahoo.com.
}

tively, and two others were collected more recently in the wild just outside Cebu City in 1999 and 2001 (Bicknell 1546, 1649). Cnidoscolus aconitifolius is one of the far less bristly species in the genus and the cultivar is used as a vegetable (label information PNH (Manuel) 18631). McVaugh (1944) classifies it in section Jussieuia (Houst.) Pax \& K.Hoffm. Breckon (in Kolterman et al. 1984) calls the cultivar C. aconitifolius subsp. aconitifolius cv. 'Chayamansa' (McVaugh) Breckon. According to him it is infertile because the pollen is abnormal, which means that the specimens collected outside Cebu City likely did not escape cultivation. It is unclear whether they were planted, present on a deserted field or whether thrown away parts rooted. The lack of other collections also indicates that the species is not invasive unlike some of the introduced Jatropha species (Van Welzen et al. 2017). According to Fernández Casas (2007) the cultivar differs from the two wild subspecies, C. aconitifolius subsp. aconitifolius and C. aconitifolius subsp. polyanthos (Pax \& K.Hoffm.) Breckon by having non-ribbed petioles when dry (vs with longitudinal ribs when dry), succulent leaf blades with flabellate, overlapping lobes (vs papery with not or hardly overlapping lobes), primary nerves raised when dry (vs nerves flat when dry); staminate flowers c. $7 \mathrm{~mm}$ long with a cylindrical perianth tube, producing abnormal pollen (vs staminate flowers 9-16 mm long with a conical or conical-cylindrical perianth tube, pollen viable); fruits unknown (vs present).

\section{TAXONOMIC TREATMENT}

Cnidoscolus aconitifolius (Mill.) I.M.Johnst. subsp. aconitifolius cv. 'Chayamansa' (McVaugh) Breckon - Fig. 1 (see note 2)

Cnidoscolus aconitifolius (Mill.) I.M.Johnst. subsp. aconitifolius cv 'Chayamansa' (McVaugh) Breckon in Kolt., Breckon \& R.R.Kowal (1984) 24. Cnidoscolus chayamansa McVaugh (1944) 466. - Type: McVaugh 494 (holo US; iso CAS, DS, F, MICH, MO, NY, S), British Honduras [Belize], Honey Camp.

Jatropha quinquelobata Mill. (1768) Jatropha species $\mathrm{n}^{\circ}$ 2. - Cnidoscolus quinquelobatus (Mill.) León (1941) 236. - Type: not indicated, reference to manuscript by Houstoun; Houstoun s.n., 1730 (BM no. 820455), Mexico, Vera Cruz, is a candidate for lectotypification.

Jatropha fragrans Kunth in Humb., Bonpl. \& Kunth (1817) 105. - Cnidoscolus fragrans (Kunth) Pohl (1827) 63. - Type: von Humboldt \& Bonpland 1333 (holo P no. 669927; iso P no. 545646), Cuba, Havana.

\section{(c) 2017 Naturalis Biodiversity Center}

You are free to share - to copy, distribute and transmit the work, under the following conditions:

Attribution: $\quad$ You must attribute the work in the manner specified by the author or licensor (but not in any way that suggests that they endorse you or your use of the work).

Non-commercial: $\quad$ You may not use this work for commercial purposes.

For any reuse or distribution, you must make clear to others the license terms of this work, which can be found at http://creativecommons.org/licenses/by-nc-nd/3.0/legalcode. Any of the above conditions can be waived if you get permission from the copyright holder. Nothing in this license impairs or restricts the author's moral rights. 
Jatropha urens L. var. inermis Calvino (1919) 364. - Cnidoscolus aconitifolius (Mill.) I.M.Johnst. subsp. aconitifolius cv. 'Inermis' (Calvino) Breckon [Cnidoscolus sect. Calyptrosolen (Euphorbiaceae) in Mexico and Central America, nom. inval., PhD thesis not distributed] ex Fern.Casas (2007) 4 nom. illeg. (based on unpublished name). - Type: Calvino s.n., 5 Dec. 1918 (USNA), Cuba, Santiago de las Vega, cultivada.

Cnidoscolus chaya Lundell (1945) 321. - Type: C.L. \& A.A. Lundell 8201 (holo LL; iso F, LL, MICH, S), Mexico, Yucatan, km 27 Mérida-Progreso Road.
Shrubs, up to $2.5 \mathrm{~m}$ high, somewhat succulent; branches up to $9 \mathrm{~mm}$ thick when dry, glabrous or locally with bristle hairs, not striate when dry, nodes thickened; juicy with translucent sap. Indumentum of bristle hairs, present in low densities on various organs, and short, woolly hairs in top of inflorescences. Stipules very early caducous, leaving thick, succulent scars. Leaves alternate, simple, concentrated towards the tips of the stems; petiole $6.2-13.5 \mathrm{~cm}$ long, not striate when dry, round
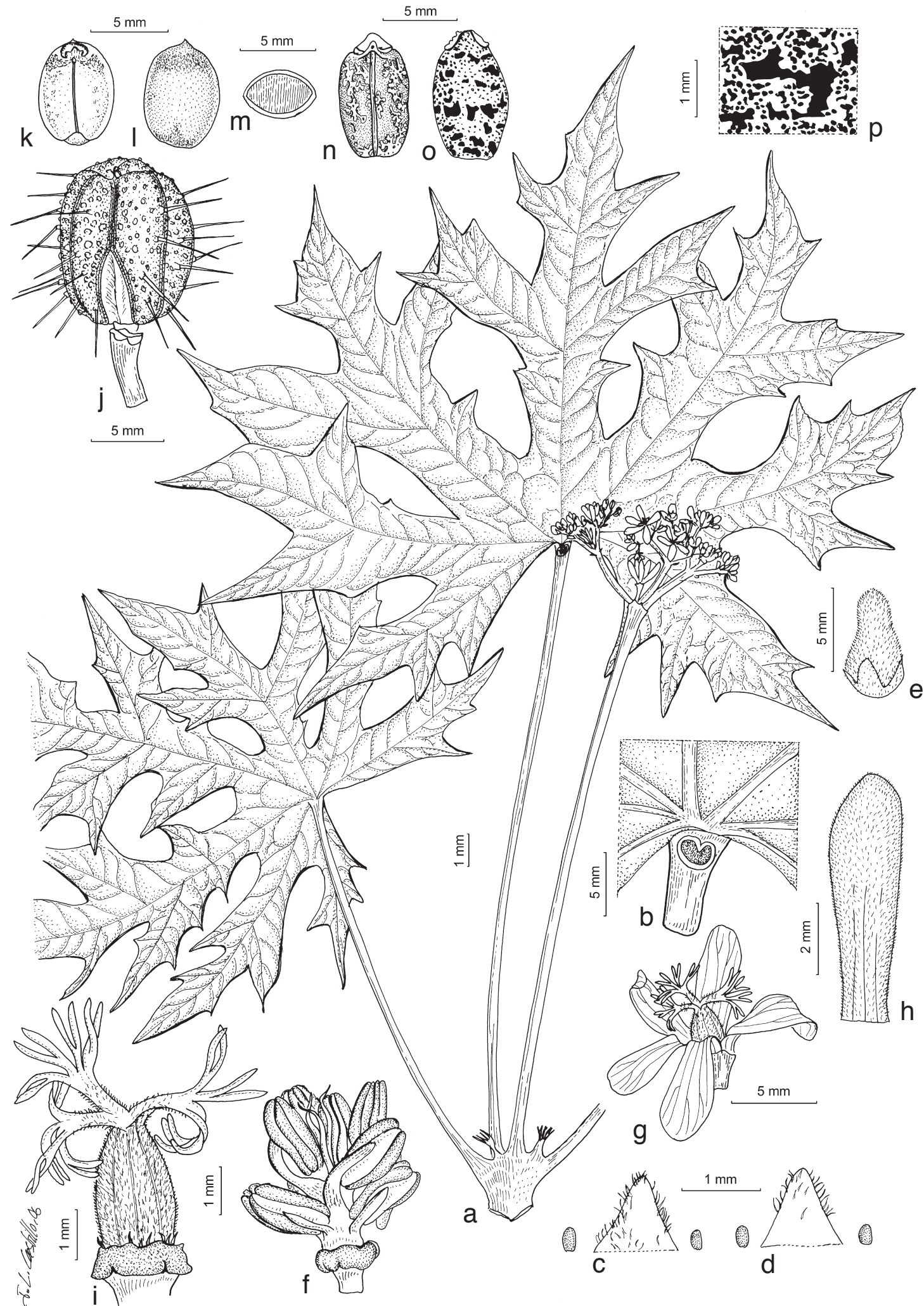

Fig. 1 Cnidoscolus aconitifolius (Mill.) I.M.Johnst. a. Habit, branch top with leaves and inflorescence; b. partly united pair of extrafloral nectaries at petiole apex; c. stipule with glands in abaxial view; d. stipule with glands in adaxial view; e. staminate bud; f. androecium and disc; g. pistillate flower; h. pistillate petal, abaxial surface; i. gynoecium, disc and staminodes; j. fruit; k. seed in ventral view; I. seed in dorsal view, m. seed in transverse section; n. seed in ventral view; o. seed in dorsal view; p. seed surface (a-i, n: T. Flynn 3319, BISH; j, o-p: R.L. Wilbur 27657, DUKE; k-m: C.L. Lundell 8201, MICH, type of C. chaya). — Drawing: J.L. Castillo, 2006. 
when fresh, glabrous, apically with a pair of elevated, touching to partly united extrafloral nectaries; blade 5-lobed, ovate, $11-21$ by $9-18.5 \mathrm{~cm}$, lobes overlapping, symmetric, papery when dry, base broadly emarginate, margin laxly serrate in especially the apical lobe parts, short and longer teeth alternating, with short bristle hairs, apices of lobes acuminate; venation basally palmate, pinnate in lobes, secondary nerves looped and touching near margin. Inflorescences terminal, dichasialsubumbelliform; peduncle up to $23.5 \mathrm{~cm}$ long, with a few short bristle hairs, especially apically woolly hairs; branches woolly hairy; bracts triangular, c. 1.2 by $0.8 \mathrm{~mm}$, apex acute, outside with woolly hairs; bracteoles like bracts, slightly smaller but with tip transformed into a gland; central flowers pistillate, more terminal/lateral ones staminate. Flowers 5-merous; calyx partly connate, lobes 5 , imbricate, petaloid, white, outside woolly hairy, apically a few short bristle-like hairs, inside glabrous; petals absent. Staminate flowers seen in bud; calyx tube c. $4.7 \mathrm{~mm}$ long, lobes obovate, c. 2.5 by $2 \mathrm{~mm}$; disc around androphore, indistinct; stamens 10, all united, outer 5 shorter, splitting off in lower part of androphore, with longer free filaments than upper and inner 5, anthers dorsi-basifixed, triangular, seemingly opening introrsely via lengthwise slits; on top of the androphore a pistillode, stigma-like, filamentous. Pistillate flowers 10-11 $\mathrm{mm}$ wide; pedicel woolly hairy, lower part of pedicel $1.5-2 \mathrm{~mm}$ long, upper c. $1 \mathrm{~mm}$ widening and continuing in calyx, persistent when calyx caducous; calyx basal c. $0.5 \mathrm{~mm}$ united (above widened part petiole), lobes oblong, c. 7 by $2.2 \mathrm{~mm}$, reflexing; disc gynophore-like, tightly around ovary and staminodes, 5-lobed, c. $0.5 \mathrm{~mm}$ high, glabrous, white; staminodes 10 , filament-like to stamen-like; ovary 3-locular, ellipsoid, c. 3 by $2 \mathrm{~mm}$, outside smooth, with woolly hairs, a single ovule per locule; style c. 0.8 $\mathrm{mm}$ long, glabrous; stigmas c. $3.3 \mathrm{~mm}$ long, $2-3$ times bifurcate, glabrous. Fruits and seeds unknown because pollen infertile.

Distribution - The species is native in Mexico and Central America, but the cultivar has a much wider distribution (Howard 1989). In Malesia only known from four Philippine collections, two cultivated in a garden, one in Manila (Luzon, garden of the collector, M.L. Steiner $1085=P N H$ (Steiner) 36973) and in Pasay City (Luzon; PNH (C.G. Manuel) 18631), two collected outside Cebu City (Cebu; D. Bicknell 1546, 1649).

Habitat \& Ecology - Outskirts of Cebu City, along stream. Altitude: 200-250 m. Flowering: June, July.

Vernacular name - Chaya (Mexican).

Uses - Young leaves and shoots are eaten as a vegetable and seemingly rich in vitamin C (Radcliffe-Smith 2001, in note, as $C$. chayamansa). This cultivar is edible because the leaf surface is quite large and it hardly has stinging, bristly hairs, which are generally very apparent in most other species in this genus.

Notes - 1. De Sessé y Lacasta (1794) published Jatropha quinqueloba and J. palmata (non Willdenow 1805; J. palmata Willd. is a synonym of $C$. aconitifolius subsp. aconitifolius) in a footnote of a printed speech by Prof. Vincente de Cervantes in the supplement of a Mexican literary newspaper. The journal is obscure, but the descriptions though brief are valid. De Sessé's J. palmata is older than Willdenow's name, making the latter illegitimate. A specimen in Madrid, 'Herbario de Sessé y Mociño 4230' (MA 602171), shows that J. palmata is a Manihot and the name is not a synonym of Cnidoscolus aconitifolius as suggested by ThePlantList.org (last checked March 2017. Jatropha quinqueloba Sessé (based on 'Herbario de Sessé y Mociño 4227', MA 602180), and closely resembling the name J. quinquelobata Mill., is identified as J. tubulosa Müll.Arg. (anonymous identification), a synonym of C. tubulosus (Müll. Arg.) I.M.Johnst. Both Jatropha names do not appear in the much later published Flora Mexicana by Sessé \& Mociño (1892-1898, of which the second edition was partly even printed earlier; not in references!).

2. The figure shows the wild type of $C$. aconitifolius, which is fertile and of which fruits are known. The cultivar has broader, leafier leaf lobes that largely overlap.

Acknowledgements The directors and keepers of herbaria that provided pictures of their types are thanked for their help. The beautiful drawing was made by J.L. Castillo.

\section{REFERENCES}

Calvino M. 1919. La mejor verdura del trópico. La Chaya. Revista de Agricultura, Comercio i Trabajo 2: 364, 365

De Sessé y Lacasta M. 1794. In: Cervantes V, Discurso pronunciado en el Real Jardin Botánico el 2 de Junio. Gazeta de Literatura Mexico, Suplemento: 1-35 (https://archive.org/details/2172033R.nlm.nih.gov).

Fernández Casas FJ. 2007. Cnidoscolorum notulae: C. aconitifolius (Miller) I.M.Johnston subsp. aconitifolius. Adumbrationes 21: 1-46.

Govaerts R, Frodin DG, Radcliffe-Smith A. 2000. World checklist and bibliography of Euphorbiaceae (and Pandaceae) 1. Royal Botanic Gardens, Kew. Grisebach AHR. 1864. Flora of the British West Indian Islands. Reeve \& Co., London.

Howard RA.1989. Flora of the Lesser Antilles 5. Arnold Arboretum, Jamaica Plain.

Kolterman DA, Breckon GJ, Kowal RR. 1984. Chemotaxonomic studies in Cnidoscolus (Euphorbiaceae). II. Flavonoids of C. aconitifolius, C. souzae, and C. spinosus. Systematic Botany 9: 22-32.

León H. 1941. Cnidoscolus y Victorinia gen. nov. en Cuba y Española. Memorias de la Sociedad Cubana de Historia Natural "Felipe Poey" 15: 235-243.

Lundell CL. 1945. The genus Cnidoscolus in Mexico: New species and critical notes. Bulletin of the Torrey Botanical Club 72: 319-334.

McVaugh R. 1944. The genus Cnidoscolus: generic limits and intrageneric groups. Bulletin of the Torrey Botanical Club 71: 457-474.

Miller P. 1768. The gardeners dictionary, 8th ed. Printed for the author, London.

Müller Argoviensis J. 1865. Euphorbiaceae. Linnaea 34: 1-224.

Müller Argoviensis J. 1866. Euphorbiaceae. In: De Candolle AP (ed), Prodromus Systematis Naturalis Regni Vegetabilis 15, 2. Victoris Masson et Filii, Paris.

Pax F. 1890. Euphorbiaceae. In: Engler A, Prantl K (eds), Die natürlichen Pflanzenfamilien 3, 5: 1-119. Engelmann, Leipzig.

Pax F. 1910. Euphorbiaceae-Jatropheae. In: Engler A(ed), Das Pflanzenreich IV.147.(i). Engelmann, Leipzig.

Pax F, Hoffmann K. 1931. Euphorbiaceae. In: Engler A, Harms H (eds), Die natürlichen Pflanzenfamilien, 2nd ed, 19c: 11-233. Engelmann, Leipzig.

Pohl JE. 1827. Plantarum Brasiliae Icones et Descriptiones 1. No publisher, Vindobonae.

Radcliffe-Smith A. 2001. Genera Euphorbiacearum. Royal Botanic Gardens, Kew.

Van Welzen PC. 1998. Revisions and phylogenies of Malesian Euphorbiaceae: Subtribe Lasiococcinae (Homonoia, Lasiococca, Spathiostemon) and Clonostylis, Ricinus, and Wetria. Blumea 43: 131-164.

Van Welzen PC, Sweet FST, Fernández Casas FJ. 2017. A revision of Jatropha (Euphorbiaceae) in Malesia. Blumea 62: 58-74.

Von Humboldt FWHA, Bonpland AJA, Kunth CS. 1817. Nova Genera et Species Plantarum 2. Sumtibus Librariae Graeco-Latino-Germinacae, Lutetiae Parisiorum.

Webster GL. 1994. Synopsis of the genera and suprageneric taxa of Euphorbiaceae. Annals of the Missouri Botanical Garden 81: 33-144.

Webster GL. 2014. Euphorbiaceae. In: Kubitzki K (ed), The families and genera of vascular plants 11, Malpighiales: 51-216. Springer Verlag, Berlin, Heidelberg.

Willdenow CL. 1805. Species Plantarum 4, 1. Nauk, Berolini.

Wurdack KJ, Hoffmann P, Chase MW. 2005. Molecular phylogenetic analysis of uniovulate Euphorbiaceae (Euphorbiaceae sensu stricto) using plastid rbcL and trnL-F DNA sequences. American Journal of Botany 92: 1397-1420. 